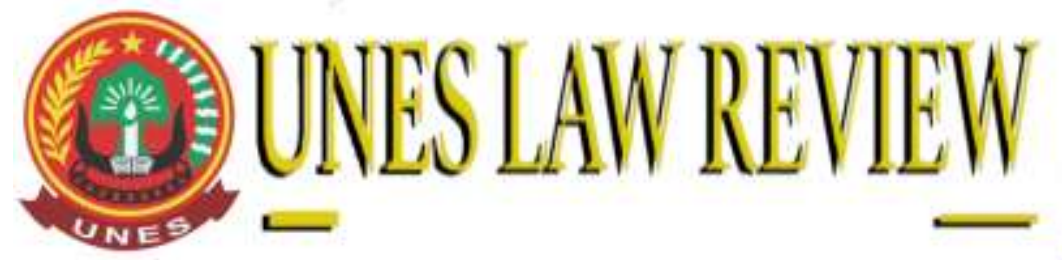

$+6282287504359$

$+6282287504359$

https://review-unes.com/

uneslawreview@gmail.com

DOI: https://doi.org/10.31933/unesrev.v3i1

Diterima: 01/10/2020, Diperbaiki: 25/10/2020, Diterbitkan: 14/11/2020

\title{
PENGATURAN DALAM UNDANG-UNDANG HAK POLITIK MANTAN TERPIDANA KASUS TINDAK PIDANA KORUPSI SEBAGAI CALON ANGGOTA LEGISLATIF PADA PEMILIHAN UMUM TAHUN 2019
}

\author{
Hamidi \\ Program Magister Ilmu Hukum, Universitas Ekasakti, Padang, Indonesia \\ Email: dihami531@gmail.com
}

Corresponding Author: Hamidi

ABSTRACT

General election is a means of democracy that is used to elect people's representatives to sit as legislative members in the MPR, DPR, DPD and DPRD. The election was conducted in accordance with Article 2 paragraph (1) of the 1945 Constitution. The 2019 election was also attended by former convicted corruption cases. This is in accordance with PKPU rules Number 20 of 2018. With this decision, an extra-judicial polemic arises which is appropriate and important to be studied more specifically and academically. The formulation of the problem in this research is, How to regulate the political rights of former convicted corruption cases as legislative candidates in the 2019 general election? What are the implications of regulating the political rights of former convicts of corruption as a candidate for legislative members in the 2019 General Elections on Human Rights? The specification of this research is normative juridical research, which is a form of research that aims to describe the applicable laws and regulations, linked to legal theories and practice of positive law enforcement, which will later be linked to the problems examined in this scientific paper. Based on the results of the analysis, answers can be obtained: 1) The Political Rights Regulation of Former Convicted Corruption Crime Cases as Legislative Candidates in the General Election Year contradicts a higher law because based on the mandate of article 4 paragraph (3) Number 20 of 2018 concerning Election Commission Regulations General as well as article 240 paragraph (1) letter ( $g$ ) of Law Number 7 of 2017 concerning General Elections. Article 28 letter d of the 1945 Constitution of the Republic of Indonesia. 2) Implications of regulating the political rights of former convicted corruption cases as candidates for legislative members in the 2019 general election against human rights, revocation of political rights for convicted corruption cases by human rights law activists (HAM) is of the view that deprivation of political rights is a violation of human rights. This is still debatable, because every sentence is basically a violation of human rights, but the violation is allowed, as long as it is based on the law.

Kata Kunci: Hak Polotik, Hak Terpidana, Tindak Pidana Korupsi, Anggota Legislatif 


\section{PENDAHULUAN}

Pemilhan Umum diartikan pemilihan yang dilakukan serentak oleh seluruh rakyat suatu Negara (untuk memilih wakil rakyat dan sebagainya) (Khairul Fahmi, 2012:20). Pemilu merupakan cara dan sarana yang tersedia bagi rakyat untuk menentukan wakil-wakilnya yang akan duduk dalam Dewan Perwakilan Rakyat guna menjalankan kedaulatan rakyat, maka dengan sendirinya terdapat berbagai sistem Pemilihan Umum. Sedangkan, "Pemilihan Umum adalah salah satu pranata yang paling representative atas berjalannya demokrasi, tidak pernah ada demokrasi tanpa pemilihan umum” (C. S. T. Kansil dan Cristine S. T, 2008:91).

Menurut Hans Kelsen dalam (Moh. Kurnadi dan Harmaily Ibrahim, 1980:115) pada dasarnya demokrasi itu adalah pemerintahan dari rakyat oleh rakyat dan untuk rakyat.3 Hal ini sejalan dengan Pasal 1 ayat 2 Undang-undang Dasar Negara Republik Indonesia tahun 1945 yang berbunyi "Kedaulatan berada di tangan rakyat dan dilaksanakan menurut Undang-undang Dasar" dapat diartikan bahwa yang melaksanakan kekuasaan.

Negara demokrasi ialah wakil-wakil rakyat yang dipilih, dimana rakyat yakin, bahwa segala kehendak dan kepentingannya akan diperhatikan di dalam melaksanakan kekuasaan Negara itu.

Dari penjelasan diatas dapat disimpulkan bahwa sebuah demokrasi yang baik akan ada pemilihan umum yang baik. Pemilihan umum yang baik mulai dari pelaksanaanya hingga aturan hukum yang mengatur masalah pemilu semata-mata mementingkan kepentingan rakyat. Sehingga dengan adanya pemilu dapat menciptakan keadilan dan kesejahteraan masyarakat yakni lahirnya pemimpin dan wakil-wakil Rakyat yang jujur terbebas dari KKN dan kejahatankejahatan yang lainnya. Pemilihan umum adalah suatu sarana demokrasi yang digunakan untuk memilih wakil wakil rakyat untuk duduk sebagai anggota legislatif di MPR, DPR, DPD dan DPRD. Wakil rakyat tersebutlah yang akan memperjuangkan kepentingan rakyat dan daerahnya. Pemilihan Umum juga merupakan sarana dari pelaksanaan kedaulatan rakyat yang diselenggarakan secara langsung, umum, bebas, rahasia, jujur dan adil guna menghasilkan pemerintahan negara yang demokratis berdasarkan Pancasila dan UUD1945.

Sesuai dengan Pasal 2 ayat (1) UUD 1945 menyatakan bahwa "Kedaulatan berada ditangan rakyat dan dilaksanakan menurut Undang Undang Dasar“. Makna dari kedaulatan ditangan Rakyat ini ialah rakyat memiliki kedaulatan, tanggungjawab, hak dan kewajiban untuk secara demokratis memilih pemimpin yang akan membentuk pemerintahan, guna mengurus dan melayani seluruh lapisan masyarakat, serta memilih wakil-wakil rakyat untuk mengawasi jalannya pemerintahan.

Di kebanyakan Negara demokrasi, pemilihan umum dianggap lambang, sekaligus tolak ukur dari sebuah demokrasi. Hasil pemilihan umum yang diselenggarakan dalam suasana keterbukaan dengan kebebasan berpendapat dan kebebasan berserikat, dianggap mencerminkan walaupun tidak begitu akurat, partisipasi dan kebebasan masyarakat. Sekalipun demikian, disadari bahwa pemilihan umum (PEMILU) tidak merupakan satusatunya tolak ukur dan perlu dilengkapi dengan pengukuran beberapa kegiatan lain yang lebih bersifat berkesinambungan, seperti partisipasi dalam kegiatan partai, lobbying, dan sebagainya. Di banyak Negara 
berkembang beberapa kebebasan seperti yang dikenal di dunia barat kurang diindahkan.Seperti Indonesia, perkembangan demokrasi di Indonesia telah mengalami pasang surut (Jimly Asshiddiqie, 2005:21).

Pemilihan umum merupakan instrumen penting untuk menuju Negara yang demokratis. Mengukur demokratis atau tidaknya penyelenggaraan pemilu, harus mengacu pada standar Internasional pemilu demokratis yang berjumlah 15 point. Standar tersebut merupakan batasan minimal yang harus terpenuhi agar sebuah penyelenggaraan Pemilu disuatu negara termasuk Indonesia bisa dianggap demokratis. Indikator dari standar tersebut meliputi 15 aspek yaitu antara lain ;

1. Penyusunan kerangka hukum

2. Pemilihan sistem pemilu

3. Penetapan daerah pemiihan

4. Hak untuk memilih dan dipilih

5. Badan penyelenggara pemilu

6. Pendaftaran pemilih dan daftar pemilih

7. Akses kertas suara bagi partai politik dan kandidat

8. Kampanye pemilu yang demokratis

9. Akses ke media dan kebebasan berekspresi

10. Pembiayaan dan pengeluaran

11. Pemungutan suara

12. Peranan wakil partai dan kandidat

13. Pemantauan pemilu

14. Penataan peraturan pemilu

15. Penegakan peraturan pemilu

Salah satu prinsip utama dari demokrasi adalah partisipasi masyarakat dalam demokrasi. Masyarakat pada nyatanya memiliki kekuatan besar dalam melakukan perubahan sosial, dengan syarat ditopang pada kesadaran kritis akan permasalahan sosial yang terjadi. Pemilu bukanlah proses lima tahunan yang hanya datang ke tempat pemilihan umum (TPS) dan memberikan hak suara, namun pemilu harus dipandang lebih jauh untuk melakukan intervensi sosial yang dilakukan masyarakat untuk mengubah permasalahan sosial yang terjadi. Salah satu bentuk intervensi sosial yang dilakukan masyarakat adalah melakukan proses penegakan hukum pemilu terhadap pelanggaran yang terjadi demi terwujudnya keadilan pemilu.

Sejatinya pemilu merupakan rangkaian empiris dari partisipasi politik publik secara lebih luas. Sejatinya pula pemilu menjadi penanda penting apakah sebuah negara sudah mampu dijalankan secara demokratis atau tidak. Pemilu adalah takdir penentu bagi institusionalisasi hakhak rakyat secara konstitusional. Bahwa pemilu adalah bagian dari dinamika politik berorientasi kekuasaan, halter sebut tidak lantas menjadikan pemilu hanya menjadi alat demi mencapai kekuasaan. Karena itu, meski secara praksis pemilu menjadi jalan bagi siapa pundan kelompok politik manapun berkuasa, tetapi secara prinsip implementatif pemilu membutuhkan reorientasi, secara struktural maupun fungsional. 
Undang-Undang Pemilu Legislatif dan Undang - Undang Pemilu Presiden menjadi alat otoritatif yang bersifat politis. Hal itu disebabkan karena kedua Undang-Undang tersebut disamping menjadi hukum pemilu juga menjadi hukum politik yang didalamnya terjadi perebutan kekuasaan. Philippe Nonet dan Philip Selznick mengungkapkan bahwa Konflik kepentingan tersebut dengan jelas mempengaruhi pembentukan UndangUndang yang akhirnya mencederai prinsip rule of law, yang juga merupakan pelindung institusional yang menghendaki pemisahan antara kehendak politik dan putusan hukum. Hukum diangkat diatas politik, artinya hukum positif ditegakkan untuk menentukan bahwa persetujuan public yang dibuktikan oleh tradisi dan proses konstitusional telah dijauhkan dari kontroversi politik. Oleh karena itu, otoritas untuk menafsirkan hukum harus dijaga sehingga terlindung dari perebutan kekuasaan dan tidak tercemar oleh pengaruh politik.

Komisi Pemilihan Umum (KPU) merupakan salah satu lembaga penyelenggara pemilihan umum di Indonesia. Lembaga ini dibentuk berdasarkan Pasal 22E Undang-Undang Dasar Negara 1945 yang menyebutkan bahwa pemilihan umum diselenggarakan oleh suatu komisi pemilihan umum yang bersifat nasional, tetap, dan mandiri. Sebagai lembaga penyelenggara pemilu, maka untuk setiap tahapan penyelenggaraan pemilu di Indonesia, KPU berwenang menyusun dan menetapkan peraturan KPU (Psl 12 dan 13 UU No. 7 Tahun 2017). Atas dasar itu pula, dalam rangka menghadapai pemilu serentak tahun 2019, KPU sebagai penyelenggara pemilu mulai berperan aktif melakukan berbagai upaya guna mewujudkan pemilu berintegritas dengan harapan tersedianya calon anggota legislatif. Untuk mencapai tujuan itu, komisioner KPU mencoba melawan arus dengan mengeluarkan gagasan berupa rancangan PKPU terkait syarat yang harus dipenuhi oleh calon anggota legislatif dengan materi muatannya adalah larangan terhadap mantan terpidana bandar narkoba, kejahatan seksual terhadap anak, atau korupsi untuk menjadi calon anggota legislatif.

Dengan Peraturan Komisi Pemilihan Umum ini dinilai KPU hanya ingin menjalankan tugasnya dengan baik. Tujuan dari aturan ini ialah untuk membersihkan para pencuri uang rakyat yang ada di parlemen yang wajib di apresiasi dalam rangka pemberantasan korupsi. Hal ini senada dengan tujuan Komisi Pemberantasan Korupsi (KPK). Berantas Koruptor dari berbagai lini. Sehingga, mantan koruptor tidak bias kembali berlaga berkiprah jadi wakil rakyat.

PKPU melarang mantan narapidana merupakan terobosan terbaru. Menumbuhkan semangat iklim pemilu yang bersih dan hadirnya gagasan ini jadi pelita bagi penyelengaraan pemilu berkualitas. KPU dalam menyelenggarakan perannya yakni memastikan pemilu berjalan adil, bersih dan tidak ada orang bermasalah didalamnya.

Penolakan tersebut terjadi didikarenaka KPU dianggap melanggar UndangUndang Republik Indonesia Nomor 7 tahun 2017 tentang Pemilihan Umum. Dalam undang-undang tersebut, mantan narapidana yang sudah menjalani masa hukuman 5 tahun atau lebih boleh mencalonkan diri sebagai anggota legislatif selama yang bersangkutan mengumumkan diri kepada public mengenai kasus hukum yang pernah menjeratnya. Selain hal tersebut, pelarangan oleh KPU di atas dianggap bertentangan dengan Pasal 28 huruf d UUD NRI Tahun 1945. 
Mantan narapidana kasus korupsi dianggap mempunyai hak politik yang sama dengan warga negara yang lain, suatu hak yang dijamin oleh konstitusi.

Akan tetapi pemilu yang harusnya berjalan dengan keinginan dan aspirasi masyarakat dibuat kisruh dengan adanya Badan Pengawas Pemilu (Bawaslu) yang meloloskan bakal caleg (bacaleg) mantan nara $\neg$ pidana korupsi menjadi caleg. Keputusan Bawaslu ini me $\neg$ mantik kegaduhan lantaran menganulir Peraturan Komisi Pemilihan Umum (PKPU) Nomor 20 Tahun 2018 tentang pencalonan anggota DPR, DPD, DPRD provinsi, kabupa $\neg$ ten, dan kota yang melarang bekas ko $\neg$ rup $\neg$ tor menjadi caleg. Putusan yang dibuat oleh Bawaslu ini tentu bertentangan dengan putusan yang telah dibuat oleh PKPU. Ihwal lolosnya caleg mantan koruptor berawal dari putusan Bawaslu daerah yang menga $\neg$ bul $\neg$ kan gugatan Syahrial Dama $\neg$ polii, bakal calon anggota DPD asal Sulawesi Utara; Abdullah Puteh, bakal calon anggota DPD Aceh; dan bacaleg DPRD Toraja Utara Joni Kornelius Tondok yang awalnya dinyatakan tidak memenuhi syarat karena ber-status eks narapidana korupsi.

Putusan Bawaslu daerah itu nyatanya "memprovokasi" bacaleg bekas koruptor lainnya melakukan perbuatan serupa. Banyak pihak berharap Bawaslu RI menunda putusan. Bawaslu daerah itu karena berᄀtentangan dengan Peraturan KPU. Alih-alih menunda, Bawaslu justru melegitimasi putusan kontroversial tersebut serta menuding Peraturan KPU men $\neg$ cederai demokrasi karena se wenang-wenang membatasi hak konstitusional warga negara. Bawaslu berdalih, demo $\neg$ krasi sejatinya menyediakan ruang terbuka bagi setiap warga untuk ikut ber $\neg$ kompe $\neg$ tisi dalam jabatan publik. KPU tak bisa melampaui hak kon $\neg$ stitusional yang melekat pada dirinya yang sebatas penye $\neg$ lenggara pemilu, bukan meng $\neg$ hambat hak politik orang lain.

Layaknya matahari kembar, KPU dan Bawaslu telah bersaing keras sejak awal pembahasan caleg bekas narapidana korupsi digulirkan ke publik. Ide keduanya nyaris tak pernah ketemu.Padahal, secara substansial pelarangan caleg koruptor sebagai upaya menyaring calon pemimpin bersih.Hanya itulah upaya yang mungkin bisa dilakukan untuk meminimalisasi kemunculan perilaku korup anggota dewan dengan mengurangi caleg bermasalah.

Secara regulasi, KPU punya otoritas membuat peraturan turunan pascaverifikasi administrasi semua caleg. Soal apakah tafsir turunan yang berupa Peraturan KPU sesuai atau tidak dengan selera publik harus disikapi secara konstitusional. Bawaslu mestinya bersabar menunggu fatwa final Mahkamah Agung (MA) karena Peraturan KPU Nomor 20 Tahun 2018 sedang digugat (judicial review) kalangan aktivis prodemokrasi. Bukan malah "bermain hakim sendiri" menerabas ketentuan yang jelas sah peruntukannya.

Akan tetapi Mahkamah Agung secara mengejutkan setelah memutus uji materi Pasal 4 ayat (3) Peraturan Komisi Pemilihan Umum (PKPU) Nomor 20 Tahun 2018 tentang Pencalonan Anggota DPR dan DPRD Kabupaten/Kota terhadap UndangUndang Nomor 7 Tahun 2017 Tentang Pemilu (UU Pemilu). Dalam putusannya, MA menyatakan bahwa larangan mantan narapidana kasus korupsi menjadi calon anggota legislative (caleg) bertentangan dengan UU Pemilu. 
Hakim Mahkamah Agung RI dalam perkara nomor 45P/HUM/2018 tersebut berpendapat, PKPU bertentangan dengan pasal 240 ayat (1) huruf g UU Nomor 7 tahun 2017 tentang Pemilihan Umum. Adanya putusan ini menandakan aturan dibuat KPU dibatalkan demi hukum. Putusan Mahkamah Agung ini tertanggal 14 September 2018 menimbulkan banyak pertentangan. Banyak pihak menyayangkan keputusan ini karena MA dianggap tidak sejalan dengan semangat untuk pemberantasan korupsi di Indonesia serta memberi ruang bagi mantan narapidana korupsi kembali melakukan mencuri uang rakyat.

Berbagai kalangan merespon putusan tersebut dengan argurnentasi yang berbeda-beda. Kondisi tersebut menimbulkan permasalahan ekstra yudisial yang patut dan penting untuk ditelaah secara lebih spesifik dan akademis. Bagian yang menarik dari putusan tersebut adalah bahwa semestinya putusan hukum menjadi parameter yang fundamental dalam menciptakan kepastian hukum bagi setiap pemangku kepentingan, tetapi realitas social terjadi sebaliknya karena putusan tersebut disertai ketidaklaziman dalam penerapan norma-norma hukum maupun kebiasaan dalam dunia peradilan sehingga menjadi kontroversial.

Dari pantauan ICW sebelumnya, hanya ada enam orang calon anggota legislatif yang tersangkut korupsi kemudian terpilih lagi dan dilantik pada tahun 2009. Atas kondisi ini, koordinator ICW Ade Irawan menyimpulkan bahwa "system rekrutmen partai sudah lemah, tidak punya elektabilitas dan integritas. Partai memilih orang-orang yang punya uang. Partai sudah memulai politik uang dari internal mereka, partai harusnya bias berbuat bijak antara lain dengan tidak meloloskan mereka atau mengganti mereka."

Pada faktanya, hanya tiga partai politik yang mendukung gagasan tersebut, yaitu PKB, PKS, dan Hanura. Sedangkan partai lain seperti Nasdem, Demokrat, PDIP, Golkar, PPP, PAN, dan Gerindra menolak gagasan tersebut untuk dimasukkan dalam rancangan PKPU sebab dinilai akan melanggar hak asasi manusia.

Jika dicermati upaya yang dilakukan KPU tersebut adalah suatu langkah progresif bagi upaya pemberantasan korupsi dalam rangka menciptakan pemerintahan yang bersih melalui pemilu legislatif, dengan mengharuskan calon anggota legislative memiliki rekam jejak yang bersih (bukan mantan terpidana) terutama tindak pidana korupsi. Akan tetapi sebagai negara hukum yang demokratis dimana setiap tindakan pemerintahan harus berdasarkan hukum maka niat baik tersebut dinilai bertentangan dengan peraturan yang ada diatasnya.

Berdasarkan uraian di atas, terdapat banyak permasalahan yang ditemui oleh sebab itu penulis tertarik untuk meninjau lebih jauh tentang Pemilu dan peilihan anggota legislatif mantan narapidana korupsi dan mengkajinya dalam suatu karya ilmiah yang berjudul "Pengaturan Dalam Undang-Undang Mengenai Hak Politik Mantan Terpidana Kasus Tindak Pidana Korupsi Sebagai Calon Anggota Legislatif Pada Pemilihan Umum Tahun 2019.”

\section{METODE PENELITIAN}

Metode yang digunakan adalah hanya pendekatan yuridis normative dengan hanya menggunakan data sekunder yang diperoleh melalui studi kepustakaan. Data tersebut kemudian di analisis secara kualitatif dan disajikan dalam bentuk deskriptif kualitatif. 


\section{HASIL DAN PEMBAHASAN \\ HASIL}

\section{Pencabutan Hak Politik Mantan Terpidana Korupsi Pada Pemilihan Umum Tahun 2019}

Berbicara mengenai hak berpolitik ialah merupakan salah satu rumpun hak asasi manusia sebagaimana diatur Pasal 25 Kovenan Internasional tentang hak-hak Sipil dan Politik. Pencabutan hak politik, khususnya hak untuk dipilih sebagai pejabat publik, adalah bentuk dari hukuman karena yang bersangkutan tidak amanah dalam memegang jabatan publik dan agar yang bersangkutan tidak bisa lagi menyalahgunakan wewenangnya. Dalam Pasal 73 UndangUndang Nomor 39 Tahun 1999 tentang Hak Asasi Manusia disebutkan, pembatasan atau pencabutan hak asasi manusia hanya diperkenankan berdasarkan undang-undang. Tujuannya, menjamin pengakuan dan penghormatan hak asasi manusia serta kebebasan dasar orang lain, kesusilaan, ketertiban umum, dan kepentingan bangsa.

Di Indonesia, penerapan pencabutan hak berpolitik dalam hal ini hak untuk dipilih dan dipilih, merupakan jenis hukum pidana tambahan yang diatur dalam KUHP. Selebihnya diterangkan dalam Pasal 10 menyatakan, Pidana Pokok, Yaitu: pidana mati, pidana penjara, pidana kurungan, dan pidana denda; Pidana tambahan, yaitu: pencabutan hak tertentu, dan pengumuman putusan hakim. Kemudian hak-hak yang dapat dicabut dengan putusan hakim diatur dalam Pasal 35 ayat (1) KUHP.

Dalam hal pencabutan hak sebagaimana diuraikan diatas, keharusan adanya pembatasan jangka waktu yang ditentukan dalam hal ini ditegaskan dalam Pasal 38 Ayat (1)dan (2) KUHP Dalam kerangka ini, pencabutan hak politik di Indonesia mendapat tempat dalam hukum positif sepanjang pencabutan hak tersebut disertai dengan jangka waktu sampai kapan hak tersebut akan dicabut.

HAM berbeda dengan hak politik. HAM adalah hak seluruh umat manusia, sedangkan hak politik adalah hak dalam kedudukan warga negara dari suatu negara tertentu. Hak tersebut berupa hak untuk memilih dan dipilih untuk menduduki jabatan publik. Hak politik dapat dibatasi dengan pencabutan yang bersifat temporer. Selanjutnya Indonesia Corruption Watch (ICW) juga merilis hasil penelitian terhadap vonis terpidana kasus korupsi selama 2017 dari pengadilan tingkat pertama hingga kasasi maupun Peninjauan Kembali (PK). Hasilnya, rata-rata vonis pidana penjara yang dijatuhkan terhadap terdakwa tipikor di tingkat pengadilan hanya 2 tahun 2 bulan penjara.

Pejabat publik yang telah terbukti merugikan keuangan Negara secara langsung yang diperuntukan untuk kepentingan umum, ekonomi, sosial, dan pendidikan. Ketiga, pencabutan hak politik dilakukan ketika terpidana telah menjalani hukumannya, serta dalam putusannya pencabutan itu tidak berdasarkan pada perhitungan secara linier tahun, tetapi pencabutan itu berdasarkan periode pemilihan baik pemilu secara umum dan pilkada. Sebab jika dilakukan pencabutan secara linier berdasarkan hitungan tahun, penulis menilai akan sia-sia apabila tidak sesuai dengan periode pemilihan. Keempat, Tidak hanya hak dipilih saja yang dicabut, tetapi kedudukan strategis dalam mengambil peran penting pada kegiatan politik untuk sementara 
selama masa hukuman pencabutan yang dijalankan tidak diperbolehkan, misalnya menjabat sebagai Badan Pengurus Harian (BPH) partai politik.

\section{Hak Politik Mantan Narapidana Menurut Putusan Mahkamah Konstitusi Nomor 14-} 17/PUUV/2007 tanggal 11 Desember 2007

Putusan Mahkamah Konstitusi Nomor 14-17/PUU-V/2007 tanggal 11 Desember 2007 dalam amar putusannya telah menolak permohonan pengujian Pasal 58 huruf f Undang-Undang Nomor 32 Tahun 2004 tentang Pemerintahan Daerah, Pasal 6 huruf t Undang-Undang Nomor 23 Tahun 2003 tentang Pemilihan Umum Presiden dan Wakil Presiden, Pasal 16 ayat (1) huruf d Undang-Undang Mahkamah Konstitusi, Pasal 7 ayat (2) huruf d Undang-Undang Nomor 5 Tahun 2004 tentang Perubahan Atas Undang-Undang Nomor 14 Tahun 1985 tentang Mahkamah Agung, dan Pasal 13 huruf g Undang-Undang Nomor 16 Tahun 2006 tentang Badan Pemeriksa Keuangan yang kesemuanya menguji syarat "tidak pernah dijatuhi pidana dengan pidana penjara berdasarkan putusan pengadilan yang telah mempunyai kekuatan hukum tetap karena melakukan tindak pidana yang diancam dengan pidana penjara 5 tahun atau lebih".

Dalam pertimbangan putusan tersebut dinyatakan pasal-pasal berbagai undang-undang yang diuji dinyatakan sebagai konstitusional bersyarat (conditionally constitutional), yakni dikecualikan untuk tindak pidana yang bersifat kealpaan ringan (culpa levis) dan tindak pidana karena alasan perbedaan pandangan politik. Hal yang menjadi pertimbangan dalam putusan ini menyangkut kekhususan-kekhususan karakter jabatan-jabatan publik tertentu menyebabkan tidak semua jabatan publik dapat ditentukan persyaratan dengan menggunakan rumusan norma yang bersifat umum sehingga perlu pembedaan persyaratan antara lain:

1. Jabatan publik yang dipilih (elected officials) dan jabatan publik yang diangkat (appointed officials);

2. Jabatan publik di bidang eksekutif yang lebih bersifat melayani dan jabatan publik di bidang legislatif yang bersifat menyalurkan aspirasi rakyat; dan

3. Jabatan publik yang karena tugasnya membutuhkan tingkat kepercayaan yang sangat tinggi, seperti hakim dan aparat penegak hukum lainnya, dan pejabat yang mengelola keuangan negara.

Tidak pernah dijatuhi pidana penjara berdasarkan putusan pengadilan yang telah mempunyai kekuatan hukum tetap karena melakukan tindak pidana yang diancam pidana penjara 5 tahun atau lebih", jika diberlakukan tanpa syarat-syarat tertentu dapat menegasi prinsip persamaan kedudukan dalam hukum dan pemerintahan serta melanggar hak seseorang atau warga negara atas perlakuan, jaminan, perlindungan, dan kepastian hukum yang adil, serta perlakuan yang sama di hadapan hukum, dan hak memperoleh kesempatan yang sama dalam pemerintahan yang pada hakikatnya merupakan moralitas hukum dan moralitas konstitusi.

Kerangka hukum mewajibkan badan pelaksana pemilihan umum menjamin penyelenggaraan pemilihan umum berlangsung secara demokratis. Berdasarkan Undang-Undang Nomor 7 Tahun 2017 tentang Pemilihan Umum, KPU diberi tugas, wewenang dan kewajiban untuk menyusun dan menetapkan peraturan KPU untuk setiap tahapan pemilu. Wewenang adalah suatu kemampuan yang diberikan oleh peraturan perundang-undangan yang berlaku untuk 
menimbulkan akibatakibat hukum. Wewenang yang dimaksud adalah wewenang yang bersifat atributif. Berdasarkan hal tersebut maka KPU sebagai lembaga penyelenggara pemilu mempunyai alas hukum untuk mengeluarkan peraturan teknis yang menjelaskan lebih detail pelaksanaan dari Undang-Undang Nomor 7 Tahun 2017 Pasal 240 ayat (1) huruf (g) tersebut dan peraturan mahkamah a quo.

\section{PEMBAHASAN}

\section{Pengaturan Hak Politik Mantan Terpidana Kasus Tindak Pidana Korupsi Sebagai Calon} Anggota Legislatif Pada Pemilihan Umum Tahun 2019.

Menjelang pelaksanaan Pemilu tahun 2019, Dewan Perwakilan Rakyat atau DPR dan Pemerintah tidak luput untuk membuat instrumen hukum baru terkait dengan Pemilu tahun 2019. Undang-Undang Nomor 7 Tahun 2017 tentang Pemilihan Umum merupakan instrumen hukum baru yang dikeluarkan untuk mengatur terkait dengan Pemilu tahun 2019. Pengaturan pada Pemilu tahun 2019 berbeda dengan pengaturan Pemilu sebelumnya khususnya sejak tahun 2004 sampai dengan tahun 2014. Pemilu tahun 2004 sampai dengan Pemilu tahun 2014 selalui mempunyai dua intrumen hukum. Instrumen hukum pertama mengatur tentang Pemilu Dewan Perwakilan Rakyat, Dewan Perwakilan Daerah, dan Dewan Perwakilan Rakyat Daerah. Instrumen hukum kedua mengatur tentang Pemilu Presiden dan Wakil Presiden.

Pemilu tahun 2019 diatur menggunakan satu instrumen hukum karena Pemilu Dewan Perwakilan Rakyat, Dewan Perwakilan Daerah, dan Dewan Perwakilan Rakyat Daerah serta Pemilu Presiden dan Wakil Presiden dilaksanakan bersama-sama atau serentak. Undang-Undang Nomor 7 Tahun 2017 sebagai instrumen hukum atau regulasi tunggal Pemilu tahun 2019 dalam kenyataannya masih terdapat beberapa kelemahan. Walaupun dapat diketahui bahwa UndangUndang Nomor 7 Tahun 2017 tentang Pemilihan Umum merupakan instrumen hukum paling komprehensif dibandingkan dengan instrumen hukum lainnya yang mengatur tentang Pemilu. Kelengkapan Undang-Undang Nomor 7 Tahun 2017 tentang Pemilihan Umum dibandingkan dengan instrumen hukum sebelumnya dapat dilihat dari banyaknya pengaturanpengaturan berkaitan dengan Pemilu. Undang-Undang Nomor 7 Tahun 2017 tentang Pemilihan Umum mempunyai kelemahan dapat dilihat dari adanya pro dan kontra di masyarakat. Adanya pro dan kontra di masyarakat terkait dengan beberapa aturan yang ada dalam Undang-Undang Nomor 7 Tahun 2017 tentang Pemilihan Umum menandakan bahwa undang-undang tersebut masih terdapat kelemahan.

Undang-Undang Nomor 7 Tahun 2017 tentang Pemilihan Umum merupakan kebijakan hukum yang dikeluarkan oleh negara dalam hal ini Pemerintah bersama DPR. Kebijakan hukum tersebut dikeluarkan untuk mewujudkan tujuan negara. Tujuan negara yang dimaksud yaitu terciptanya sistem pemilihan umum di Indonesia yang kuat, demokratis, adil, terintegrasi, terjamin, berkepastian hukum, serta efektif dan efisien. Tujuan tersebut yang harus diwujudkan oleh Undang-Undang Nomor 7 Tahun 2017 tentang Pemilihan Umum. Oleh karena itu pelaksanaan dan penegakan hukum terhadap UndangUndang Nomor 7 Tahun 2017 tentang 
Pemilihan Umum ahrus dilakukan dengan benar dan baik sehingga cita-cita sistem pemilihan umum di Indonesia dapat terwujud.

Peraturan KPU Nomor 20 Tahun 2018 tentang Pencalonan Anggota Dewan Perwakilan Rakyat, Dewan Perwakilan Rakyat Daerah Provinsi, dan Dewan Perwakilan Rakyat Daerah Kabupaten/Kota adalah peraturan yang ditetapkan oleh KPU pada 30 Juni 2018 lalu dan termasuk kategori peraturan perundang-undangan yang mengikat dan berlaku sebagai hukum positif.

Pengaturan dalam Peraturan KPU No. 20 Tahun 2018 menjadi perbincangan karena beberapa substansinya mengatur mengenai adanya pembatasan hak untuk turut berpartisipasi dalam pemerintahan bagi mantan narapidana. Antara lain Pasal 4 ayat (3) Peraturan KPU No. 20 Tahun 2018 memberikan persyaratan bagi Partai Politik dalam mengajukan bakal calon anggota legislatif yaitu, "Dalam seleksi bakal calon secara demokratis dan terbuka sebagaimana dimaksud pada ayat (2), tidak menyertakan mantan terpidana bandar narkoba, kejahatan seksual terhadap anak, dan korupsi." Bahkan, penegasan tersebut harus dituangkan secara jelas dalam salinan pakta integritas yang harus di tandatangani oleh pimpinan partai politik di setiap tingkatan yang mengikuti pemilu.

Implikasi Pengaturan Hak Politik Mantan Terpidana Kasus Tindak Pidana Korupsi Sebagai Calon Anggota Legislatif Pada Pemilihan Umum Tahun 2019 Terhadap Hak Asasi Manusia.

Indonesia merupakan Negara hukum yang di tegaskan dalam UndangUndang Dasar Negara Republik Indonesia Tahun 1945 Pasal 1 ayat (3) dan salah satu dari ciri-ciri negara hukum adalah menjunjung tinggi hak asasi manusia dan menjamin semua warga negara sama kedudukannya di depan hukum dan pemerintahan tanpa terkecuali. Diperinci lebih lanjut dalam Undang Dasar Negara Republik Indonesia Tahun 1945 Pasal 28C ayat (2) yang menyatakan bahwa setiap orang berhak memajukan dirinya dalam memperjuangkan hak secara kolektif untuk membangun masyarakat, bangsadan negaranya dan Pasal 28D ayat (3) dimana setiap warga Negara berhak memperoleh kesempatan yang sama dalam pemerintahan.

Pasal 1 ayat (2) UUD 1945 menyatakan bahwa kedaulatan berada di tangan rakyat dan dilaksanakan menurut ketentuan Undang-Undang Dasar. Pasal 1 ayat (3) UUD 1945 menyatakan bahwa negara Indonesia adalah Negara hukum. Berdasarkan rumusan pasal tersebut jelas bahwa negara Indonesia wajib menjamin terlaksananya sebuah pemilihan umum yang bebas tanpa terkecuali, sebagai bukti bahwa Indonesia merupakan negara hukum. Pada konteks ini pemilihan kepala daerah dan pemilihan umum berada pada dimensi hukum sebagai wujud hak asasi manusia. Adanya prinsip persamaan di muka hukum harus diartikan ketidak berpihakan terhadap setiap warga masyarakat di mata hukum sehingga dapat dituntut dengan derajat yang sama tanpa membeda-bedakannya. Hak Asasi Manusia (HAM) merupakan hak hukum yang berusaha menerjemahkan keyakinan tentang martabat manusia ke dalam bahasa hukum yang konkret dengan tujuan agar hak-hak itu seperlunya dapat dipaksakan pelaksanaanya di depan pengadilan. Konsepsi HAM dalam perkembangannya sangat terikat dengan konsepsi negara hukum. Dalam sebuah negara hukum sesungguhnya yang memerintah adalah hukum, bukan manusia. Hukum 
dimaknai sebagai kesatuan hirarkis tatanan norma hukum yang berpuncak pada konstitusi. Hal ini berarti bahwa dalam sebuah Negara hukum menghendaki adanya supremasi konstitusi. Supremasi konstitusi di samping merupakan konsekuensi dari konsep negara hukum sekaligus merupakan pelaksanaan demokrasi karena konstitusi merupakan wujud perjanjian sosial tertinggi.

Implikasi terhadap eks narapidana yang terbatasi hak politiknya karena adanya syarat "Tidak pernah dijatuhi pidana penjara berdasarkan putusan pengadilan yang telah mempunyai kekuatan hukum tetap karena melakukan tindak pidana yang diancam dengan pidana penjara 5 (lima) tahun atau lebih". (Pasal 50 ayat 1. g), merupakan pelanggaran terhadap Hak Asasi Manusia (HAM) dan diskriminasi politik, masalah diskriminasi, dan segala bentuk ketidak pedulian adalah masalahmasalah yang sangat berpengaruh kepada kehidupan keseharian manusia, cara hidup manusia, cita-cita manusia dan impian mereka (eks narapidana).

\section{KESIMPULAN}

Pengaturan Hak Politik Mantan Terpidana Kasus Tindak Pidana Korupsi Sebagai Calon Anggota Legislatif pada Pemilihan Umum tahun 2019 yaitu dengan mengacu pada peraturan mengenai Pemilihan Umum Nomor 20 Tahun 2018 yang mengatur tentang pencalonan legislatif. Dalam UndangUndang Nomor 7 Tahun 2017 Tentang Pemilihn Umum menyatakan Bahwa bakal calon DPR, DPR Provinsi, dan DPRD Kabupten/Kota adalah warga Negara Indonesia harus memenuhi syarat tidak pernah dipidana penjara berdasarkan putusan pengadilan tetap karena melakukan tindak pidana yang di ancam dengan pidana penjara 5 (lima) tahun atau lebih, kecuali secara terbuka dan jujur mengemukan kepada public bahwa yang bersangkutan mantan narapidana. Penolakan tersebut terjadi dikarenakan KPU melanggar UndangUndang Republik Indonesia Nomor 7 tahun 2017 tentang Pemilihan Umum.

Implikasi pengaturan hak politik politik mantan terpidana kasus tindak pidana korupsi sebagai calon anggota legislatif pada Pemilihan Umum Tahun 2019 terhadap Hak Asasi Manusia yaitu Ketentuan pencabutan hak, Mahkamah Konstitusi memberikan tafsir dalam putusan Nomor 4/PUUVII/ 2009 yang memutus bahwa hukuman pencabutan hak politik itu dianggap konstitusional dengan batasan pencabutan hak hanya berlaku sampai 5 tahun sejak terpidana selesai menjalankan hukumannya.

\section{DAFTAR PUSTAKA}

Afan Gaffar, Politik Indonesia Menuju Transisi Demokrasi, Pustaka Pelajar Jakarta, 1996

Affan Gaffar, Politik, Demokrasi, dan Faham Integralistik (Dalam Buku Kedaulatan Rakyat, Hak Asasi Manusia dan Negara Hukum), Penerbit Gaya Media Pratama, Jakarta, 2010.

Astim Riyanto, Filsafat Hukum, Yapemdo, Bandung, 2002

Bagir Manan dan Kuntana Magnar, Kedaulatan Rakyat, Hak Asasi Manusia, Negara Hukum. Kumpulan Esai Guna Menghormati Prof. Dr. R. Sri Soemantri M, S.H. Gaya Media Pratama, Jakarta, 1996 
Budiono Kusumohamidjojo, Ketertiban yang Adil (Problematik Filsafat Hukum), Grasindo, Jakarta, 1999

C. S. T. Kansil dan Cristine S. T. Kansil, Hukum Tata Negara Republik Indonesia, Rineka Cipta, Jakarta, 2008

Franz Magnis Suseno, Etika Politik, Gramedia Pustaka Utama, Jakarta, 2001

Jimly Asshiddiqie, Format Kelembagaan Negara dan Pergeseran Kekuasaan Dalam UUD 1945, FH UII Press, Yogyakarta, 2005

Hans Kelsen, General Theory of Law and State, New York Russell \& Russell, 1973

Indroharto, Usaha Memahami Undangundang Tentang Peradilan Tata Usaha Negara, Pustaka Sinar Harapan, Jakarta, 1991

Khairul Fahmi, Pemilihan Umum \& Kedaulatan Rakyat, Rajawali Pers, Jakarta, 2012.

Lili Rasjidi, "Pembangunan Sistem Hukum dalam Rangka Pembinaan Hukum Nasional," dalam Butir-butir Pemikiran dalam Hukum: Memperingati 70 Tahun Prof. Dr. B. Arief Sidharta, SH. Penyunting Sri Rahayu Oktoberina dan Niken Savitri. Cetakan Pertama, Refika Aditama, Bandung, 2008

Moh. Kurnadi dan Harmaily Ibrahim, Pengantar Hukum Tata Negara Indonesia, Sinar Bakti, Jakarta, 1980

Mohammad Hatta, Kearah Indonesia Merdeka (1932) Dalam Kumpulan Karangan, Jilid I, Bulan Bintang, Jakarta, 1976

Undang-Undang Nomor 7 Tahun 2017 Tentang Pemilihan Umum

Undang-Undang Nomor 39 Tahun 1999 Tentang Hak Asasi Manusia

Undang-Undang Nomor 5 Tahun 2004 Tentang Kekeuasaan Kehakiman

Undang-undang Nomor 42 Tahun 2008 tentang Pemilihan Umum Presiden dan Wakil Presiden.

Undang-undang Nomor 15 Tahun 2011 tentang Penyelenggara Pemilihan Umum.

Undang-undang Nomor 8 Tahun 2012 tentang Pemilihan Umum Anggota Dewan Perwakilan Rakyat, Dewan Perwakilan Daerah, dan Dewan Perwakilan Rakyat Daerah 